\title{
Pendekatan Sanitasi untuk Pemulihan Kondisi Air Tanah di Perkotaan Studi Kasus : Kota Cimahi, Jawa Barat
}

\author{
Sanitation Approach for Recovering Groundwater Condition \\ in Urban Area \\ Case Study : Cimahi City, West Java \\ ELIS HASTUTI DAN RENI NURAENI \\ Pusat Litbang Perumahan dan Permukiman, Balitbang, Kementerian Pekerjaan Umum dan Perumahan Rakyat \\ Jalan Panyaungan, Cileunyi Wetan, Kabupaten Bandung \\ elishastuti@yahoo.com
}

\begin{abstract}
The increasing uses of both groundwater resources and unproper on-site sanitation in urban dense settlement have caused the decline of groundwater level and contamination. This study aims to get groundwater consumption level and development of artificial groundwater recharge in Bandung Groundwater Basin, especially in Cimahi City, West Java. Management of groundwater recharge at urban settlements can be done by using the approach of sanitation, including the method of groundwater recharge from surface water or treated water of wastewater treatment plant. Therefore, the classification of groundwater zones which are at the safe zone to be sustainable and at the prone to critical zone will need prevention and treatment at the recharge source. It was predicted that the rainfall artificial recharge can produce an increase of $84.97 \%$ from the total amount of recharge water naturally at groundwater zone in Cimahi City. The increasing use of pit latrines has impact to groundwater quality can be prevented by development of wastewater treatment at communal scale to produce treated water that can be reused for groundwater recharge. The treated water from communal wastewater treatment plants for groundwater recharge is important to consider land availability, simplicity of operation and maintenance and public health. Associated with sanitation development, the wastewater treatment system should consider multiple processing stages which can consist of biofilm systems, subsurface constructed wetlands then inducted to groundwater through shaft of granular filtration.
\end{abstract}

Keywords : Groundwater, recharge, sanitation, rainfall, treated water

\begin{abstract}
ABSTRAK
Peningkatan pemanfaatan air tanah dan sarana sanitasi setempat yang tidak dikelola di permukiman padat telah berdampak negatif terhadap sistem air tanah, dengan terjadi penurunan muka air tanah dan pencemaran air tanah. Penelitian ini bertujuan untuk memperoleh tingkat pemakaian air dan pengembangan pengelolaan air imbuhan di zona-zona pemanfaatan air tanah Cekungan Air Tanah (CAT) Bandung, khususnya di Kota Cimahi, Jawa Barat. Pengelolaan air imbuhan di permukiman perkotaan dapat dilakukan dengan pendekatan sanitasi, diantaranya melalui metoda resapan air tanah dari air hujan atau dari air olahan suatu instalasi pengolahan air limbah. Sehingga klasifikasi zona aman air tanah dapat berkelanjutan dan zona rawan atau kritis dapat dilakukan pencegahan dan penanganan di sumber imbuhan. Peresapan curah hujan buatan (artificial recharge) di zona-zona pemanfaatan air tanah dapat menghasilkan peningkatan sebesar $84,97 \%$ dari jumlah total air yang teresapkan secara alami. Sementara itu berkembangnya sanitasi on site dengan sistem cubluk, cenderung mencemari air tanah. Hal ini dapat dicegah dengan pengelolaan air limbah skala lingkungan, yang bertujuan menghasilkan air olahan yang dapat digunakan kembali atau untuk pengisian air tanah. Pengisian air tanah dari air olahan instalasi pengolahan air limbah skala lingkungan penting untuk mempertimbangkan ketersediaan lahan, kemudahan pengelolaan dan kesehatan masyarakat. Beberapa cara diantaranya dapat menerapkan beberapa tahap pengolahan dengan sistem biofilm, lahan basah buatan sistem aliran di bawah permukaan kemudian pengisian air tanah melalui filtrasi granular.
\end{abstract}

Kata kunci : Air tanah, imbuhan, sanitasi , air hujan, air olahan

\section{PENDAHULUAN}

Meningkatnya aktivitas perkotaan dan industrialisasi memiliki efek mendalam pada sumberdaya air, khususnya pada air tanah. Hal tersebut terkait erat dengan pemakaian air tanah untuk mencukupi kebutuhan hidup serta untuk proses produksi ${ }^{(1)}$. Dampak aktivitas perkotaan dan berkembangnya sarana sanitasi yang tidak layak di permukiman padat terhadap sistem air tanah dapat merubah sistem imbuhan air tanah 
dan siklus imbuhan air tanah, dengan perubahan sumber-sumber imbuhan.

Salah satu penyebab terjadinya pencemaran air tanah berkaitan dengan kurangnya akses ketersediaan infrastruktur air bersih dan sanitasi. Di kawasan permukiman padat, keberadaan sarana sanitasi yang belum memenuhi persyaratan teknis atau kesehatan berdampak pada kesehatan dan ekologi lingkungan karena potensi sumber imbuhan/pencemaran air limbah melalui resapan tanah sangatlah tinggi, yang dipengaruhi pula oleh hidrologi dan kondisi tanah $^{(2)}$. Sementara itu pemanfaatan air tanah terus meningkat dari tahun ke tahun dan apabila tidak dikelola dengan baik akan menyebabkan terjadi penurunan muka air tanah yang diikuti oleh krisis air tanah, penurunan muka tanah dan pencemaran air tanah. Untuk mengantisipasi dampak pembangunan permukiman di kawasan cekungan air tanah, maka upaya pelestarian lingkungan dapat dilakukan dengan pendekatan pengelolaan sanitasi yang berkelanjutan atau pendekatan berbasis purifikasi/daur ulang alam. Kerusakan lingkungan di kawasan cekungan air tanah, dapat ditangani dengan pendekatan tersebut, yang keberhasilan penerapannya ditentukan oleh kondisi lahan, potensi alam dan juga partisipasi masyarakat.

Air tanah adalah air yang bergerak dalam tanah yang terdapat di dalam ruang-ruang antara butir-butir tanah atau dalam retakan-retakan batuan $^{(3)}$. Pengelolaan air tanah yang saling menunjang (Conjuctive water management), tidak hanya menangani sumber daya air secara pendekatan teknis saja dengan paradigma hanya suplai air yang menjadi tujuan utama dasar manusia, pertanian, dan industri. Namun juga melalui pendekatan 'sustaining ecological system' dimana dengan perspektif ekologi dapat menjamin pemenuhan air secara berkelanjutan dan secara tidak langsung mendukung keberlanjutan cekungan air tanah. Konservasi air tanah diantaranya dilakukan dengan pengelolaan air imbuhan, termasuk air limpasan dan air limbah domestik. Komposisi air limbah domestik didominasi oleh air (99,9\%), sedikit bahan padat yang terdiri dari organik (protein $65 \%$, karbohidrat $25 \%$, dan lemak $10 \%$ ) dan anorganik (butiran, garam, dan metal). Namun, seiring dengan kemajuan bioteknologi, muncul bahan biologi jenis lain, seperti surfaktan, organic priority pollutant, dan volatileorganic ${ }^{(4)}$.

Isu utama masalah air tanah pada perkembangan suatu kota di Indonesia adalah interaksi antara urbanisasi dengan sistem air tanah di bawahnya, apalagi jika kota tersebut terletak di atas suatu sistem akuifer bebas ${ }^{(5)}$. Interaksi ini sangat tergantung pada pola dan tahapan perkembangan kota. Jika laju pengambilan air tanah dari sejumlah sumur jauh lebih besar dari pengisiannya, maka lengkunglengkung penurunan muka air tanah antara sumur satu dengan lainnya akan menyebabkan terjadinya penurunan muka air tanah secara permanen. Pendekatan perlindungan dan pelestarian air tanah dapat dilakukan melalui keberlanjutan sanitasi, diantaranya dengan menjaga daya dukung dan fungsi daerah imbuhan air tanah, dengan cara pemeliharaan kelangsungan fungsi air dan daerah tangkapan air dan pengisian air pada sumber air $^{(6)}$. Imbuhan air tanah merupakan air yang terinfiltrasi dan mampu menambah cadangan air $\operatorname{tanah}^{(7)}$.

Pengisian air tanah diantaranya dapat dilakukan dengan penambahan resapan air hujan/air permukaan atau air olahan dari instalasi pengolahan air limbah (IPAL). Pengisian air tanah didefinisikan sebagai aliran air untuk mencapai muka air dengan mekanisme difusi yang ditujukan untuk penambahan penampungan air $\operatorname{tanah}^{(8)}$. Pada pengelolaan air limbah di perkotaan secara konvensional mempertimbangkan sebagai proses linier dengan input (air limbah tercampur) pada satu ujung dan output (buangan hilir pada efluen terolah dan pembuangan lumpur) pada ujung lainnya. Kebutuhan sumber air untuk non potable water dapat disediakan dari beberapa sumber seperti air daur ulang dan air hujan dan dapat disimpan didalam akuifer karena jumlahnya yang besar $^{(9)}$. Sehingga pada pendekatan terintegrasi, dilakukan berdasarkan proses cyclic yang diamati di alam dimana pengumpulan secara terpisah untuk pengolahan dan daur ulang urine, feses, grey water dan air hujan. Pada pengelolaan IPAL terdesentralisasi diharapkan dilakukan berbasis masyarakat, yang apabila dikelola secara mandiri dan terprogram menjadi salah satu bentuk kesuksesan keberlanjutan sanitasi. Oleh karena itu pemberdayaan masyarakat harus ditingkatkan untuk mencapai kualitas lingkungan yang baik ${ }^{(10)}$. Pendekatan ini dipertimbangkan sebagai solusi yang lebih berkelanjutan dan dapat diaplikasikan untuk meningkatan kinerja pengolahan karena menggunakan biaya yang lebih sedikit dan menggunakan sumberdaya untuk didaur ulang sehingga lebih efisien ${ }^{(11)}$.

Tujuan penelitian pendekatan sanitasi untuk pemulihan kondisi air tanah di perkotaan adalah untuk memperoleh karakteristik pemanfaatan air tanah dan pengembangan pengelolaan air imbuhan di zona-zona air tanah di Cekungan Air Tanah (CAT) Bandung, khususnya di Kota Cimahi, Jawa Barat.

\section{BAHAN DAN METODE}

\subsection{Tempat dan Waktu Penelitian}

Penelitian ini dilakukan di Cekungan Air Tanah (CAT) Bandung khususnya di Kota 
Cimahi, Jawa Barat yang terletak diantara $107^{\circ} 30^{\prime} 30^{\prime \prime}-107^{\circ} 34^{\prime} 30^{\prime \prime}$ Bujur Timur dan $6^{\circ} 50^{\prime} 00^{\prime \prime}-6^{\circ} 56^{\prime} 00^{\prime \prime}$ Lintang Selatan, luas wilayah Kota Cimahi adalah 40,23 $\mathrm{km}^{2}(4.023,73 \mathrm{Ha})$. Sumber air tanah merupakan sumber air utama untuk hampir semua aktivitas perkotaan di Kota Cimahi, dan penurunan muka air tanah di Kota Cimahi sebesar 3 sampai 4 meter per tahun ${ }^{(12)}$.

\subsection{Cara Penelitian}

Identifikasi tingkat pemakaian air dilakukan melalui pendekatan komunikasi dan observasi data terstruktur melalui pertemuan/diskusi dengan masyarakat. Penentuan responden dilakukan dengan metoda sampling yaitu proporsional random sampling. Data kondisi air tanah diperoleh melalui survey muka air tanah di sumur air tanah, kualitas air tanah dan lingkungan fisik air tanah selama tahun 2013 dan tahun 2014. Metoda analisis data dilakukan berdasarkan analisis deskriptif kualitatif dan kuantitatif, yang dibagi menjadi beberapa kategori sebagai berikut: rumah tangga, komersial dan industri, militer, umum. Analisis kualitas air tanah dilakukan di lapangan dan di laboratorium, meliputi parameter TDS, pH,besi, mangan. Sementara itu, peta zona pemanfaatan air tanah disusun berdasarkan basis data spasial, baik data grafik maupun data atribut dengan Sistem Informasi Geografis (SIG). Analisis overlay dilakukan berdasarkan data tata ruang, hidrogeologi, iklim, kependudukan dan tingkat pemakaian air serta peta potensi air tanah di Kota Cimahi.

\section{HASIL DAN PEMBAHASAN}

Pemanfaatan air tanah yang dilakukan secara efisien dan efektif perlu disertai upaya pemeliharaan kuantitas dan pengendalian kerusakan kualitas air tanah. Pengelolaan imbuhan air tanah dengan resapan dan pengendalian pencemaran air limbah domestik dapat berdampak pada kawasan cekungan airtanah dengan struktur perkotaan diatasnya. Adanya perubahan alih fungsi lahan, infrastruktur pengelolaan air yang tidak memadai di kawasan perkotaan menyebabkan imbuhan air hujan dan kualitas air tanah semakin menurun.

\subsection{Tingkat pemakaian air}

Di lokasi studi, kedudukan geografis Kota Cimahi yang sangat strategis dan memiliki potensi sebagai sentra kegiatan pelayanan jasa, terutama industri, pendidikan, pariwisata dan perdagangan, menyebabkan peningkatan pengambilan sumber daya air tanah. Berdasarkan data potensi air di Kota Cimahi, diketahui bahwa sumber air potensial di Kota Cimahi terdiri dari air tanah (mata air, air tanah dangkal dan air tanah dalam) dan air permukaan (danau/kolam dan Sungai Cimahi) ${ }^{(13)}$. Pengambilan air tanah umumnya dilakukan sebagian besar dengan menggunakan sumur bor untuk usaha industri, usaha komersial lainnya atau masyarakat, dimana beberapa pengambilan air tanah telah melebihi kapasitas yang diijinkan dalam SIPA/Surat Izin Pengambilan Air Bawah $\operatorname{Tanah}^{(14)}$.

Tingkat pemakaian air domestik mencakup pemakaian air untuk aktivitas di lingkungan rumah tangga. Berdasarkan data RTRW Kota Cimahi tahun 2012-2032, kebutuhan air domestik di lokasi studi sekitar $115 \mathrm{~L} / \mathrm{o} /$ hari $^{(15)}$. Sedangkan berdasarkan hasil survei lapangan (Gambar 1), terindentifikasi pemakaian air di Kecamatan Cimahi Utara sekitar 72,1-91,5 L/o/h, di Kecamatan Cimahi Tengah sekitar 79,5-122 L/o/h dan di Kecamatan Cimahi Selatan sekitar $58,5-66,9 \mathrm{~L} / \mathrm{o} / \mathrm{h}$. Terdapat faktor-faktor yang mempengaruhi besaran tingkat pemakaian air tersebut, diantaranya tingkat sosial ekonomi, aktivitas penduduk, dan lain-lain. 


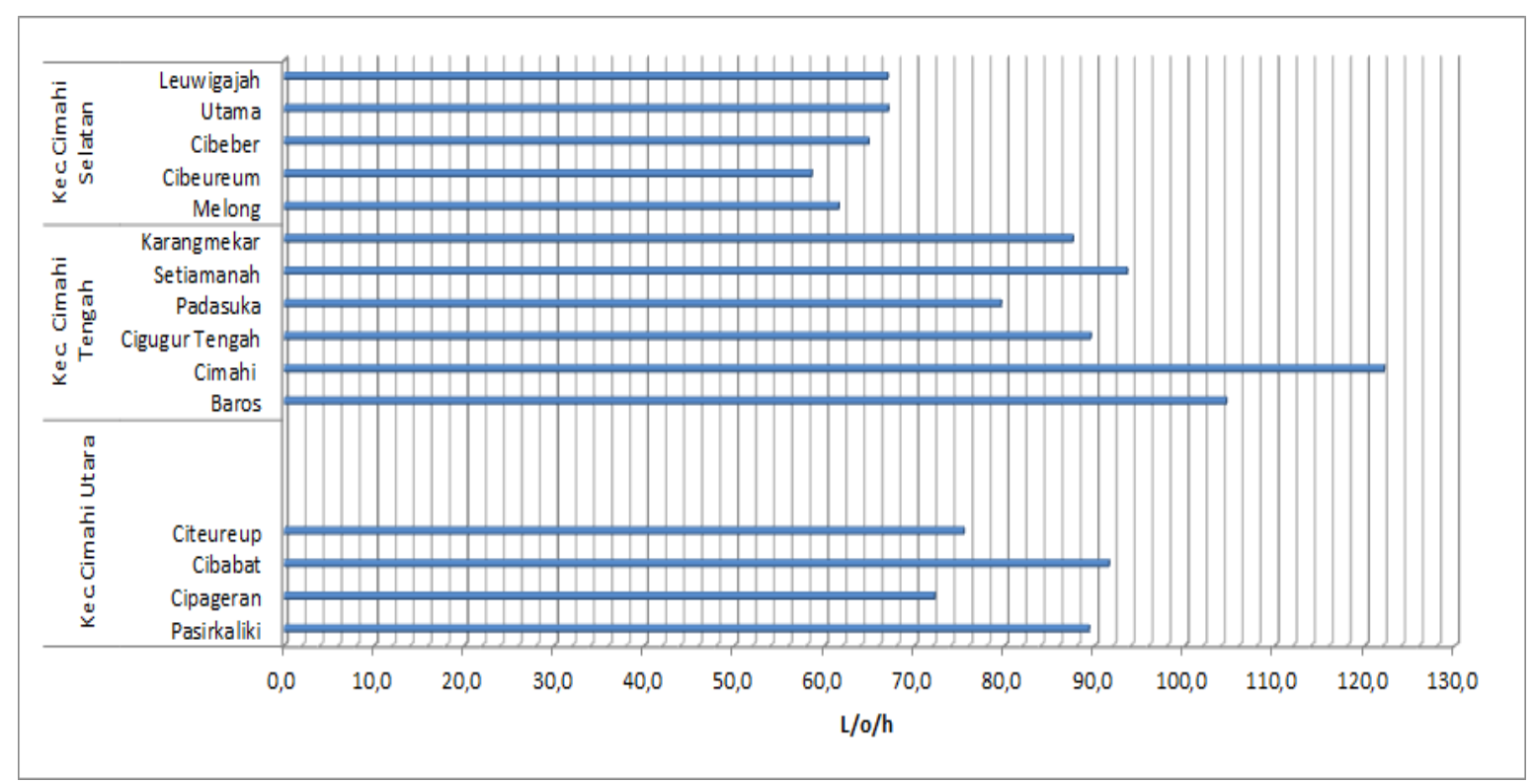

Gambar 1 . Distribusi tingkat pemakaian air domestik di Kota Cimahi

Penyediaan air untuk kebutuhan non domestik meliputi sarana-sarana seperti instansi pemerintah, sarana perniagaan, perusahaan industri serta sarana sosial/pendidikan/kesehatan serta fasilitas umum. Berdasarkan data RTRW Kota Cimahi tahun 2012-2032 ${ }^{(15)}$, kebutuhan air untuk industri/pabrik atau unit usaha lainnya, komersial, adalah sekitar 50-80 L/h. Hasil identifikasi terhadap kebutuhan air non domestik di Kota Cimahi terdiri dari kebutuhan air domestik seperti untuk kantin, kamar mandi, dan lain- lain, serta kebutuhan air non domestik untuk memenuhi penunjang proses produksi dan untuk proses produksi sendiri. Tingkat pemakaian air pada sektor industri bervariasi tergantung pada seberapa besar dan jenis industri yang ada, jumlah pekerja dan juga luas lahan. Pemakaian air industri berdasarkan proses atau jenis industri serta jumlah pekerja pada industri tersebut. Untuk pekerja industri besar, membutuhkan kebutuhan air sekitar 30-50 L/o/h, sedangkan khusus di proses industri tekstil menunjukkan kebutuhah air lebih dari 30000 L/h. Pada kategori industri sedang membutuhkan air > $4000 \mathrm{~L} / \mathrm{h}$ yang diidentifikasi meliputi industri makanan, industri pelapisan logam. Sementara itu pemakaian air untuk kepentingan umum sekitar 3000-8500 L/h, termasuk untuk mencukupi kebutuhan air bersih pada gedung pemerintah dan pelayanan pemerintah termasuk pada gedung gedung umum, sekolah, pembersihan jalan, penyiraman taman kota, pemadam kebakaran dan lain sebagainya.

Adapun berdasarkan hasil proyeksi jumlah penduduk Kota Cimahi dengan metoda eksponensial, pada tahun 2030 mencapai 1.224.883 orang dan kebutuhan air tanah yang harus tersedia sekitar 57,98 juta $\mathrm{m}^{3}$ per tahun.
Pemenuhan kebutuhan air tersebut dari sumber air permukaan dan air tanah diperkirakan berdasarkan perencanaan peningkatan pelayanan perpipaan oleh PDAM dengan proporsi sumber air bakunya $40 \%$ dari air permukaan dan $60 \%$ dari air tanah. Sedangkan pelayanan non perpipaan umumnya dari sumur dangkal/dalam pribadi dan pemerintah juga melakukan pemboran air tanah.

\subsection{Pengaruh imbuhan terhadap kualitas air tanah}

Pengendalian pemanfaatan air tanah perlu dilakukan untuk menghindari pengambilan air tanah secara berlebihan yang dapat mengakibatkan berbagai dampak negatif. Sumber imbuhan air tanah di CAT Bandung tidak hanya berasal dari air hujan namun berasal dari sumber lainnya yaitu imbuhan air tanah dari kawasan pemukiman dan pesawahan, air permukaan dan dari transfer antar akifer ${ }^{(7)}$. Lingkungan fisik merupakan faktor utama yang mempengaruhi pengisian dan pengambilan air tanah. Lapisan air tanah dangkal merupakan lapisan air tanah yang lebih mudah terpengaruh oleh kondisi lingkungan di daerah tersebut.

Pada lapisan tanah dangkal kualitas dan kuantitas air tanah lebih bersifat fluktuatif, dipengaruhi oleh air permukaan, sementara kontinuitasnya tergantung infiltrasi. Kualitas air tanah yang digunakan sebagai sumber air minum harus memenuhi persyaratan fisik, kimiawi, bakteriologis dan radioaktifitas. Diperkirakan kualitas air tanah dengan batasan kedalaman hingga 20 - $40 \mathrm{~m}$ bagian atas dari sistem akuifer, sangat terancam oleh pencemaran dari daerah padat penduduk.Sedangkan pada air tanah 
dalam, umumnya memiliki kuantitas relatif cukup, kualitas cukup baik namun kontinuitas tidak terjamin. Air tanah dari akuifer dalam dapat mempunyai resiko pencemaran tinggi, jika terjadi bocoran dari akuifer dangkal. Berdasarkan sampling air tanah secara komposit di beberapa lokasi, diperoleh hasil pengujian kualitas air tanah sesuai tabel 1. Pada umumnya kualitas air tanah memenuhi persyaratan fisik dan beberapa persyaratan kimia, antara lain $\mathrm{pH}$, TDS, besi dan mangan.Sedangkan parameter kekeruhan pada sumber air sumur dangkal, dapat disebabkan oleh adanya bahan anorganik yang tersuspensi dan terlarut, seperti lapisan tanah, pasir halus atau partikel partikel lainnya yang terbawa oleh limpasan air permukaan ataupun bahan organik seperti mikroorganisma, tanaman, dan lain-lain. Selain itu keberadaan sumur dangkal yang berdekatan dengan drainase yang buruk atau cubluk atau tangki septik, dapat berpotensi mencemari air tanah.

$\mathrm{Di}$ lokasi studi tersebut dapat terjadi pengaruh negatif dari berkembangnya sanitasi on site sistem cubluk terhadap kontaminasi bakteri pada air tanah. Penelitian kualitas air tanah yang aman dari kontaminasi bakteri terjadi pada jarak horizontal lebih dari $5,5 \mathrm{~m}$ dan jarak vertikal $\geq$ 3-4,5 m dari dasar cubluk ke muka air tanah pada kondisi basah dan kering. Beberapa penelitian juga menyebutkan jarak kontaminasi bakteri E.Coli, total Coliform and bakteri anaerob, dipengaruhi oleh saturasi tanah dan kecepatan aliran air tanah ${ }^{(2)}$.Sehingga agar sumur terhindar dari pencemaran ini, maka yang harus diperhatikan jarak sumur dengan tangki septik, galian lubang resapan dan sumber pembuangan limbah ${ }^{(16)}$.

Kualitas air tanah dengan kekeruhan lebih dari 5 NTU, memiliki kandungan warna yang tinggi pula namun tidak berkorelasi positif dengan kekeruhan, karena warna air disebabkan selain bahan tersuspensi juga dapat bahan terlarut seperti oksida logam besi atau mangan $^{(17)}$. Kualitas air tanah dangkal di kawasan Cimahi Selatan atau yang berdekatan dengan kawasan yang telah tercemar industri, belum teridentifikasi pencemaran ke arah air tanah dangkal. Sedangkan pada kualitas air tanah dalam di kawasan industri, umumnya memiliki padatan terlarut yang tinggi, kemungkinan karena kandungan ion-ion penyebab kesadahan. Industri yang tidak memiliki pengolahan air limbah yang tepat dapat berpotensi mencemari air permukaan yang berdampak dapat mencemari air tanah. Untuk mendapatkan kualitas air minum sesuai Keputusan Menteri Kesehatan RI Nomor 492/MenKes/SK/IV/2010, diperlukan beberapa tahap pengolahan untuk mencapai baku mutu air minum.

Tabel 1. Karakteristik kualitas air tanah di beberapa lokasi

\begin{tabular}{|c|c|c|c|c|c|c|c|c|c|c|}
\hline \multirow[t]{2}{*}{ No } & \multicolumn{2}{|c|}{ Jenis Sumur } & \multirow{2}{*}{$\begin{array}{c}\text { SDK } \\
\text { Citeureup } \\
\text { RW 5 }\end{array}$} & \multirow{2}{*}{$\begin{array}{c}\text { SDL } \\
\begin{array}{c}\text { Kantor Lurah } \\
\text { Citeureup }\end{array}\end{array}$} & \multirow{2}{*}{$\begin{array}{c}\text { SDL } \\
\text { Utama } \\
\text { RW 12 }\end{array}$} & \multirow{2}{*}{$\begin{array}{c}\text { SDK } \\
\text { Cibeber } \\
\text { RW } 19\end{array}$} & \multirow{2}{*}{$\begin{array}{c}\text { SDL } \\
\text { Industri } \\
\text { Makanan }\end{array}$} & \multirow{2}{*}{$\begin{array}{c}\text { SDL } \\
\text { Industri } \\
\text { Tekstil }\end{array}$} & \multirow{2}{*}{$\begin{array}{c}\text { SDL } \\
\text { Industri } \\
\text { Pelapisan } \\
\text { Logam } \\
\end{array}$} & \multirow{2}{*}{$\begin{array}{c}\text { Permenkes } \\
492 / \text { menkes/ } \\
\text { per/IV/2010 }\end{array}$} \\
\hline & Parameter & Satuan & & & & & & & & \\
\hline \multicolumn{11}{|c|}{ Fisik } \\
\hline 1 & Warna & PtCo & 10 & 1 & 4 & 1 & 5 & 6 & 4 & 15 \\
\hline 2 & Temperatur & ${ }^{0} \mathrm{C}$ & 25 & 24,7 & 24,7 & 24,7 & 25 & 25 & 24,7 & - \\
\hline 3 & Kekeruhan & NTU & 10,8 & 0,52 & 0,47 & 0,31 & 0,27 & 0,86 & 0,21 & 5 \\
\hline 4 & $\begin{array}{c}\text { TDS } \\
\text { Kimia }\end{array}$ & $\mathrm{mg} / \mathrm{L}$ & 241 & 213 & 258 & 235 & 687,4 & 563,5 & 389,9 & 500 \\
\hline 1 & $\mathrm{pH}$ & - & 7,25 & 7,17 & 7,04 & 6,93 & 8,28 & 8,59 & 8,59 & $6,5-8,5$ \\
\hline 2 & Kesadahan & $\mathrm{mg} / \mathrm{L}$ & 134 & 124 & 124 & 120 & 324 & 150 & 190 & 500 \\
\hline 3 & Nitrat $\left(\mathrm{NO}_{3}\right)$ & $\mathrm{mg} / \mathrm{L}$ & 3,07 & 5,96 & 0,08 & 1,35 & 0,16 & 0,93 & 0,44 & 50 \\
\hline 4 & Nitrat $(\mathrm{N})$ & $\mathrm{mg} / \mathrm{L}$ & 0,69 & 1,35 & 0,02 & 0,3 & 0,04 & 0,21 & 0,10 & \\
\hline 5 & Nitrit $\left(\mathrm{NO}_{2}\right)$ & $\mathrm{mg} / \mathrm{L}$ & 0,28 & 0,009 & 0,82 & 0,006 & 0,15 & 0,34 & 0,07 & 3 \\
\hline 6 & Nitrit (N) & $\mathrm{mg} / \mathrm{L}$ & 0,09 & 0,003 & 0,25 & 0,002 & 0,04 & 0,10 & 0,02 & \\
\hline 7 & Ammonia & $\mathrm{mg} / \mathrm{L}$ & $<0,01$ & $<0,01$ & 0,22 & $<0,01$ & 0,10 & 0,05 & 0,11 & 1,5 \\
\hline 8 & Ammonia $(\mathrm{N})$ & $\mathrm{mg} / \mathrm{L}$ & $<0,01$ & $<0,01$ & 0,17 & $<0,01$ & 0,08 & 0,04 & 0,08 & \\
\hline 9 & Klorida & $\mathrm{mg} / \mathrm{L}$ & 18,26 & 34,39 & 33,85 & 3,72 & 109,9 & 97,22 & 27,49 & 250 \\
\hline 10 & Sulfat & $\mathrm{mg} / \mathrm{L}$ & 1,0 & 31 & 72 & 38 & 31 & 120 & 78 & 250 \\
\hline 11 & Besi & $\mathrm{mg} / \mathrm{L}$ & 0,09 & 0,09 & 0,15 & 0,15 & 0,17 & $<0,0001$ & $<0,0001$ & 0,3 \\
\hline 12 & Mangan & $\mathrm{mg} / \mathrm{L}$ & $<0,0001$ & $<0,0001$ & 0,28 & $<0,0001$ & $<0,0001$ & $<0,0001$ & 0,02 & 0,4 \\
\hline
\end{tabular}

Sumber : Lab. Balai AMPLP, Puslitbang Permukiman, Nopember 2014

Pengelolaan air tanah melalui pengelolaan air imbuhan perlu terus dilakukan untuk meningkatkan kualitas air tanah sehingga klasifikasi zona air tanah di Kota Cimahi yang berada pada zona aman dapat berkelanjutan (Gambar 2). Apabila klasifikasi zona berdasarkan kualitas air tanah tersebut mengalami penurunan, maka pencegahan dan penanganan di sumber-sumber potensial imbuhan atau pencemaran perlu segera dilakukan. Ancaman kesehatan akan meningkat dengan mengkonsumsi kualitas air yang berada di luar zona aman, sehingga pengolahan air lengkap perlu dilakukan dan penyisihan kandungan TDS yang tinggi akan memerlukan biaya yang cukup tinggi. 


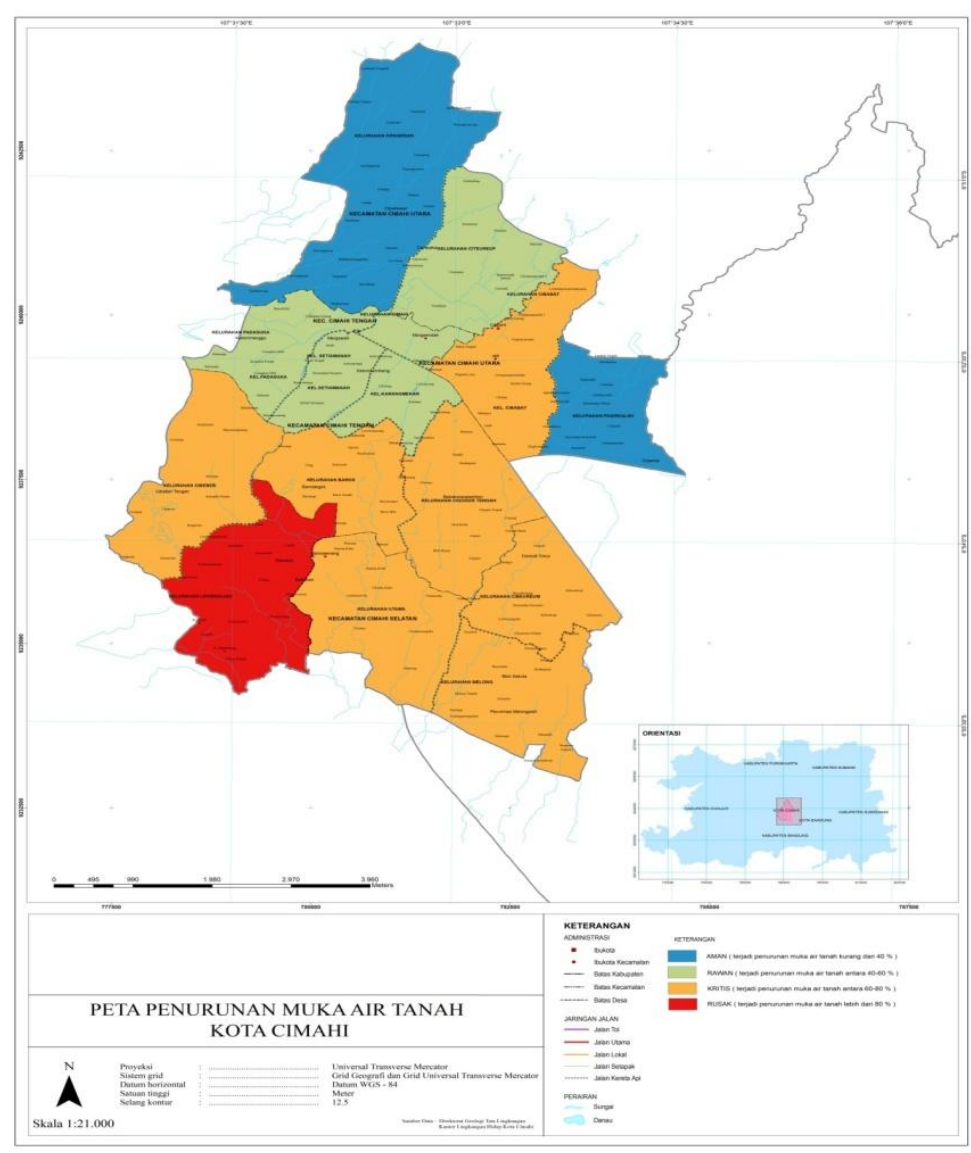

Gambar 2. Zona Konservasi air tanah di Kota Cimahi

\subsection{Pengelolaan sanitasi berkelanjutan}

Peningkatan aktivitas penduduk di permukiman diiringi dengan peningkatan kebutuhan air baik domestik maupun non domestik. Sumber daya air yang memadai harus dikelola untuk dapat memenuhi kebutuhan air secara kuantitas, kualitas dan kontinuitas. Berdasarkan hasil kajian penelitian "Simulasi Numerik dalam Hidrologi" (18), zona kritis penurunan muka air tanah di Cekungan Bandung pada tahun 2013 diprediksi meningkat $116 \%$ dari tahun 2000 , dan zona rusak meningkat $570 \%$. Berdasarkan analisis penurunan muka air tanah di lokasi studi, yang diilustrasikan di gambar 2, potensi air tanah di bagian tengah digolongkan pada zona pengambilan air tanah kritis. Wilayah tersebut meliputi Kelurahan Cimahi, Leuwigajah, Cibabat, Pasirkaliki, Baros, Setiamanah dan Karangmekar. Kawasan strategis dari sudut kepentingan fungsi dan daya dukung lingkungan menurut RTRW Kota Cimahi 2012-2032, meliputi seluruh wilayah Kecamatan Cimahi Utara dan sebagian Kecamatan Cimahi Tengah, khususnya Kelurahan Cimahi, dan bagian utara Kelurahan Padasuka Setiamanah, Karangmekar dan Cigugur Tengah, dengan luas sekitar $1.600 \mathrm{Ha}$ atau sekitar $40 \%$ luas Kota Cimahi. Bagian utara Kota Cimahi terlingkup pada Kawasan Bandung
Utara (KBU) dimana mempunyai kemampuan tinggi untuk meresapkan air hujan, kemiringan lebih dari $30 \%$. Sementara itu hutan lindung berada di sebagian Kecamatan Leuwigajah dan sebagian Kelurahan Padasuka. Disamping bagian utara Kota Cimahi yang dijadikan sebagai kawasan resapan air, terdapat kawasan lindung di Kota Cimahi yang dapat difungsikan sebagai kawasan tangkapan/resapan air yang terdapat di sebagian Kelurahan Leuwigajah dan Kelurahan Padasuka. Sebagian wilayah di kawasan resapan air tersebut telah terbangun (built up area) sampai ketinggian $800 \mathrm{~m}$ dpl (sekitar 1.000 $\mathrm{Ha}$ ), sebagian terbangun (setempat-setempat) sampai ketinggian $850 \mathrm{~m}$ dpl (sekitar $350 \mathrm{Ha}$ ), dan sisanya merupakan lahan pertanian dan "permukiman perdesaan" (sekitar $250 \mathrm{Ha}$ ) di Kelurahan Cipageran dan Citeureup ${ }^{(19)}$.

Kawasan resapan air tersebut merupakan kawasan budidaya terbatas, sehingga perkembangan jumlah penduduk Kota Cimahi yang memiliki kecenderungan ke arah utara Kota Cimahi perlu dikendalikan. Kegiatan permukiman harus mengikuti peraturan zonasi mengenai koefisien dasar bangunan serta pengembangan permukiman kepadatan rendah, agar di bagian utara Kota Cimahi ini masih memiliki fungsi sebagai kawasan resapan air. Sumber air 
imbuhan dari permukaan ataupun pencemaran terhadap akuifer dangkal akan mengancam air tanah dalam sebagai sistem yang terletak dibawahnya, maka perlu dilakukan pengelolaan air imbuhan. Arahan konservasi air tanah dengan penghijauan dan artificial recharge berdasarkan penggunaan lahan di Kota Cimahi, seperti diuraikan pada tabel 2 .

Metode pemulihan kondisi muka air tanah sedekat mungkin ke kondisi alamiah, dapat dilakukan dengan melakukan peresapan curah hujan buatan (artificial recharge). Peresapan buatan untuk memperbesar tampungan air tanah dari limpasan permukaan, antara lain seperti sumur resapan, reservoir permukaan, parit resapan, sumur injeksi atau taman resapan air hujan.

Pada Tabel 2, menunjukkan peningkatan infiltrasi buatan sebesar $84,97 \%$ dari jumlah total air teresapkan secara alami atau $7,37.10^{6} \mathrm{~m}^{3} / \mathrm{thn}$. Upaya tersebut sangatlah penting karena limpasan permukaan pada musim hujan dapat berkurang dan pada musim kemarau, cadangan air tanah tidak berkurang. Peresapan buatan tersebut terutama ditujukan untuk menghilangkan zona rawan, kritis dan rusak. Pertimbangan pemilihan lokasi resapan dilakukan berdasarkan penggunaan lahan, karakteristik tanah dan juga kecepatan pemulihan permukaan air tanah dimana kawasan tersebut termasuk zona rawan. Sedangkan peresapan buatan yang dilakukan di luar zona tersebut, juga penting dilakukan untuk mempercepat peresapan air. Namun jika peresapan buatan dilakukan diluar zona rawan, kritis atau rusak maka akan diperlukan waktu yang lebih lama sebelum air dari peresapan buatan dapat mencapai zona tersebut.

Peningkatan jumlah penduduk dan pertumbuhan industri, pengambilan air tanah akan terus meningkat dengan dampak-dampak negatif. Kondisi eksisting pengelolaan air limbah di lokasi studi pada umumnya dilakukan secara individual dengan menggunakan cubluk atau dibuang langsung ke saluran/sungai, dan sebagian kawasan juga telah menerapkan IPAL komunal. Mengingat bahwa air tanah di Kota Cimahi adalah sumber daya yang perlu dipelihara kelestariannya, maka bukan hanya penurunan muka air tanah (MAT) lebih lanjut yang perlu dicegah, tetapi diperlukan juga tindakan untuk memulihkan kondisi MAT sedekat mungkin ke kondisi alamiah. Upaya konservasi air tanah dengan cara teknis konstruktif dapat juga dilakukan dengan meresapkan air hasil olahan pengolahan air limbah skala komunal/ lingkungan. Air tanah dangkal memiliki karakteristik kuantitas terbatas, kualitas tergantung air permukaan dan kontinuitas tergantung infiltrasi, sementara itu hampir sebagian besar masyarakat menggunakan pengolahan limbah setempat yang cenderung mencemari air tanah ${ }^{(21)}$. Sedangkan pada air tanah dari akuifer dalam juga dapat mempunyai resiko pencemaran tinggi, jika terjadi kebocoran dari akuifer dangkal.

Tabel 2. Peningkatan infiltrasi air tanah

\begin{tabular}{|c|c|c|c|c|c|c|c|}
\hline \multirow[t]{3}{*}{ No } & \multirow[t]{3}{*}{ Tata Guna Lahan } & \multirow{3}{*}{$\begin{array}{c}\text { Luas } \\
(\mathrm{Ha})\end{array}$} & \multicolumn{2}{|c|}{ Koefisien Limpasan Permukaan } & \multicolumn{3}{|c|}{ Infiltrasi $\left(\mathrm{m}^{3} / \mathrm{th}\right)$} \\
\hline & & & Sebelum & Sesudah & Alami & Penghijauan & $\begin{array}{c}\text { Artifisial } \\
\text { Recharge }\end{array}$ \\
\hline & & & \multicolumn{2}{|c|}{ Penghijauan } & & & \\
\hline \multirow[t]{6}{*}{1.} & Kawasan Lindung & & & & & & \\
\hline & Hutan Lindung & 404,7 & 0,32 & 0,32 & $2,75 E+06$ & & \\
\hline & Cagar Budaya & 20,81 & 0,62 & 0,32 & $7,91 \mathrm{E}+04$ & $3,75 \mathrm{E}+04$ & \\
\hline & $\begin{array}{l}\text { Perlindungan } \\
\text { setempat }\end{array}$ & 386,72 & 0,62 & 0,32 & $1,47 E+06$ & $6,96 \mathrm{E}+05$ & \\
\hline & $\mathrm{RTH}$ & 30,05 & 0,62 & 0,32 & $1,14 \mathrm{E}+05$ & & \\
\hline & $\begin{array}{l}\text { Perlindungan } \\
\text { lainnya }\end{array}$ & 205,52 & 0,62 & 0,32 & $7,81 \mathrm{E}+05$ & $3,70 \mathrm{E}+05$ & \\
\hline \multirow[t]{7}{*}{2.} & Kawasan Budidaya & & & & & & \\
\hline & Permukiman & 1534,33 & 0,95 & 0,32 & $7,67 \mathrm{E}+05$ & & $5,80 \mathrm{E}+06$ \\
\hline & $\begin{array}{l}\text { Perdagangan dan } \\
\text { Jasa }\end{array}$ & 284,7 & 0,95 & 0,62 & $1,42 E+05$ & & $1,88 \mathrm{E}+05$ \\
\hline & Industri & 640,96 & 0,95 & 0,62 & $3,20 E+05$ & & $8,46 \mathrm{E}+05$ \\
\hline & Pariwisata (air) & 67,77 & 0,2 & 0,2 & $5,42 \mathrm{E}+06$ & & \\
\hline & Peruntukan lainnya & 450,14 & 0,62 & 0,32 & $1,71 E+06$ & & $5,40 \mathrm{E}+05$ \\
\hline & Jumlah & & & & $8,68 \mathrm{E}+06$ & $1,10 \mathrm{E}+06$ & $7,37 \mathrm{E}+06$ \\
\hline
\end{tabular}

Sumber : Hasil analisis, 2015;

Keterangan $^{(20)}$ :

Curah hujan : $2250 \mathrm{~mm} / \mathrm{th}$

Evapotranspirasi (ET) : $1250 \mathrm{~mm} / \mathrm{th}$

Evapotranspirasi untuk artificial recharge : $20 \% \times \mathrm{ET}$

Kebutuhan penutupan bangunan (KTB) : $50 \mathrm{~m}^{2} / \mathrm{kapita}$

Building coverage ratio (BCR) : 40 
Sehingga pendekatan pengelolaan air limbah skala lingkungan di lokasi studi sangat penting, dengan tujuan menghasilkan air olahan yang aman dibuang ke lingkungan sekitar atau memenuhi kualitas air yang dapat digunakan untuk pengisian air tanah. Terkait program pembangunan IPAL skala lingkungan, dimana sistem tersebut akan terintegrasi ke dalam satu sistem di masa yang akan datang.

Air limbah yang dapat diresapkan ke tanah harus dapat memenuhi baku mutu Permen KLHK no 68 tahun 2016 atau air daur ulang USEPA 2014 untuk recharge air tanah $(\mathrm{pH} \mathrm{6-9,}$ BOD $\leq 10 \mathrm{mg} / \mathrm{L}$, TSS $\leq 30 \mathrm{mg} / \mathrm{L}$, kekeruhan $\leq 2$ NTU, E.Coli tidak ada). Salah satu rencana implementasi daur ulang air, berada di kawasan Cibabat yang menerapkan dua tipe unit IPAL komunal kapasitas masing masing $100 \mathrm{KK}$. Sistem pengolahan dipilih berdasarkan diskusi dengan masyarakat, pendekatan praktis, keterbatasan lahan, kemudahan pengelolaan serta manfaat estetika dari taman pengolahan air limbah, yang terdiri dari sistem biofilm terendam dan lahan basah buatan aliran dibawah permukaan serta filtrasi granular $^{(22)}$. Penerapan lahan basah buatan dibawah aliran permukaan ini memberikan keuntungan dengan menghindari kontak langsung dengan efluen yang akan diolah, menghilangkan masalah bau yang tidak sedap dan gangguan serangga ${ }^{(23)}$.

Di salah satu kawasan di Kelurahan Cibabat, sebagian besar masyarakat membuang air limbah ke saluran drainase, hasil pemeriksaan kualitas air di saluran drainasemempunyai nilai BOD lebih dari $100 \mathrm{mg} / \mathrm{L}$. Kondisi saluran drainase yang ada, sebagian memiliki konstruksi yang sudah retak dan dangkal sehingga air limbah dapat mencemari air tanah dan menimbulkan kondisi septik di lingkungan sekitar. Kualitas air tanah yang digunakan penduduk dapat dipengaruhi oleh air permukaan dan berpotensi infiltrasi air limbah dari saluran drainase yang telah retak atau meluap.Adapun berdasarkan karakteristik dikawasan Cibabat tersebut, direncanakan terdapat dua alternatif penerapan pengolahan air limbah yang salah satunya dapat ditujukan untuk pengisian air tanah yaitu dengan diagram alir seperti ditunjukkan pada Gambar 3.
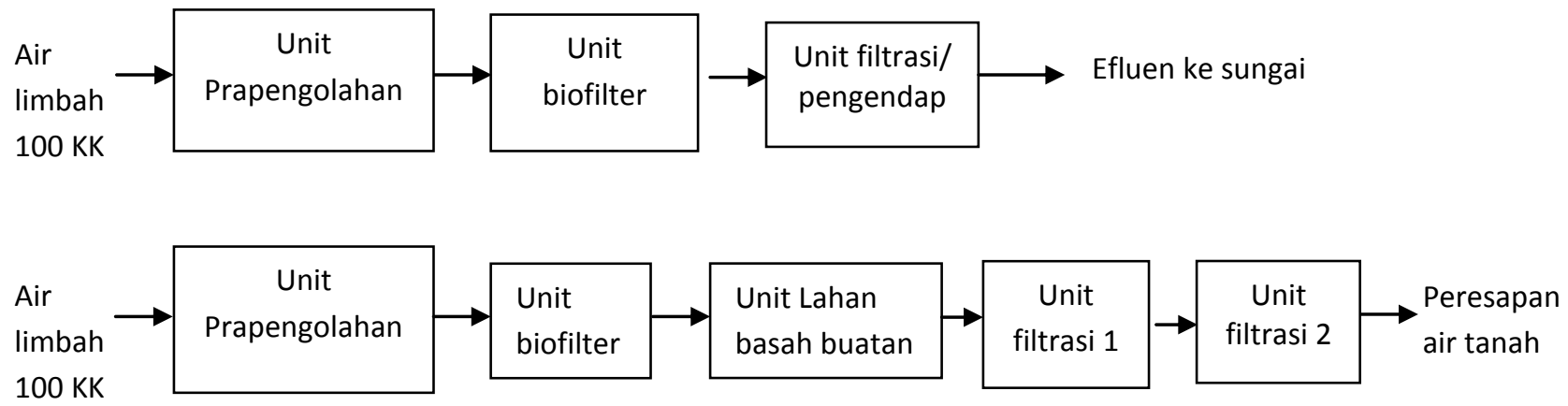

Gambar 3.Skema pengolahan air limbah pada IPAL-1 dan IPAL-2

Pengisian air tanah dari air olahan IPAL skala lingkungan membutuhkan pengolahan lanjutan setelah pengolahan primer atau sekunder dan tergantung pada sumber air limbah dan metoda pengisian air tanah. Pengolahan beberapa tahap diperlukan untuk daur ulang air limbah dengan mempertimbangkan perhatian terhadap kista protozoa, virus enterik and trace organikdidalam air minum. Di USA telah menerapkan surface method/pengisian air tanah dengan kolam penampung air untuk penyebaran air olahan IPAL ke dalam tanah setelah melaluipengolahan primer, sekunder dan tersier air limbah dengan filtrasi granular serta desinfeksi dengan khlorin ${ }^{(24)}$. Sementara itu metoda pengisian air tanah dengan subsurface method, diantaranya denganmengaplikasikan pengolahan air limbah dengan sistem kolam stabilisasi kemudian dialirkan ke sumuran berisi pasir untuk infiltrasiperkolasi dengan laju $1 \mathrm{~m} /$ hari kemudian air tanah tersebut digunakan kembali untuk perkebunan tomat ${ }^{(24)}$. Pengisian air tanah dengan subsurface method, merupakan pilihan yang layak di perkotaan untuk mengurangi kebutuhan air dan meningkatkan daur ulang air limbah ${ }^{(25)}$. Pengelolaan air limbah berbasis daur ulang tersebut juga berkaitan dengan wilayah lainnya dan siklus air serta perencanaan perkotaan secara keseluruhan sehingga dapat memberikan manfaat pada sektor maupun di luar sektor sanitasi. Diantaranya dapat meningkatkan akses sanitasi dengan sistem desentralisasi dan pengoperasian dan pemeliharaan yang mudah serta dapat mengurangi beban infrastruktur secara terpusat. Manfaat lainnya didalam penghematan air dengan mendaur ulang air limbah untuk irigasi, pengisian aquifer terutama 
selama musim kemarau dan penggunaan air non potable, yang dapat mengurangi kebutuhan air.

\section{KESIMPULAN}

Pemenuhan kebutuhan air yang sebagian besar dari sumber daya air tanah di Kota Cimahi, apabila tidak diiringi upaya pengelolaan air tanah dapat menimbulkan dampak negatif berupa penurunan muka air tanah maupun kualitas air tanah.Tingkat pemakaian air domestik di Kota Cimahi berbeda-beda di setiap kawasan, yang menunjukkan pemakaian air di Cimahi Utara sekitar 72,1-91,5 L/o/h, di Cimahi Tengah sekitar 79,5-122 L/o/h dan di Cimahi Selatan sekitar 58,5 $-66,9 \mathrm{~L} / \mathrm{o} / \mathrm{h}$. Pada sektor non domestik, tingkat pemakaian air tanah dipengaruhi oleh peruntukkan lahan, jenis atau proses produksi.Pengelolaan imbuhan air tanah melalui resapan dan pengendalian pencemaran air limbah domestik dapat berdampak terutama pada kawasan cekungan air tanah dengan struktur perkotaan di atasnya.Melalui pengaturan dan konservasi air tanah, diantaranya peresapan buatan diperlukan untuk meminimasi zona rawan, kritis dan rusak dimana zona rawan pemanfaatan air tanah kemungkinan bertambah di Kecamatan Cimahi Utara. Pengisian air tanah dari air olahan instalasi pengolahan air limbah skala lingkungan penting untuk mempertimbangkan ketersediaan lahan, kemudahan pengelolaan dan kesehatan masyarakat, diantaranya dapat menerapkan beberapa tahap pengolahan dengan sistem biofilm, lahan basah buatan sistem aliran dibawah permukaan kemudian pengisian air tanah melalui filtrasi granular.

\section{PERSANTUNAN}

Penulis mengucapkan terima kasih kepada Puslitbang Perumahan dan Permukiman serta Pemerintah Kota Cimahi yang telah membantu dalam penyusunan tulisan ini.

\section{DAFTAR PUSTAKA}

1. Putranto, Triadi, Thomas, (2011), Aliran Air Tanah Dalam Konsep Pengelolaan Air Tanah berbasis Cekungan. Proceeding Olimpiade Karya Tulis Inovatif (OKTI).

2. Graham, P., Jay, and P. L., Matthew, (2013), Pit Latrines and Their Impacts on Groundwater Quality: A Systematic Review. Environmental Health Perspectives, vol. 121, No. 5.

3. Prawati, E., (2011), Studi dan Pemodelan Air Tanah Akibat Pemompaan. Tapak, Vol.1, no.1.
4. Hindarko, S., (2003), Mengolah Air Limbah. Jakarta: Penerbit Esha Seri Lingkungan Hidup.

5. Hendrayana, H., (2012), Dampak Pemanfaatan Air Tanah. Geological Engineering Dept., Faculty of Engineering, Gadjah Mada University.

6. Kodoatie R.J, dan R. Sjarief, (2008), Pengelolaan Sumber Daya Air Terpadu. Ed rev. Yogyakarta: Penerbit Andi.

7. Nurliana, Leni, Widodo, Eko, dan Lilik, (2009), Potensi Imbuhan Dan Imbuhan Air Tanah Cekungan Air Tanah Bandung. JTM Vol. XVI No. 4/2009/261.

8. Blarasin M., L. Maldonado, F. Becher Quinodoz, N. Alincastro, A. Cabrera, E. Matteoda, J. G. Albo, (2015), Assessment Of Groundwater Recharge And Discharge Processes In A Loessical Aquifer Using A New Computer Code. Journal Of Environmental Hydrology, Vol. 23.

9. Daigger, T., and Glen, (2008), New Approaches and Technologies for Wastewater Management. The Bridge FallTechnologies for Clean Water, vol. 38, No. 3.

10. Hafidh, Ridwan , Kartika, Fibriliana , Farahdiba, Ulfah, dan Aulia, (2016), Keberlanjutan Instalasi Pengolahan Air Limbah Domestik (IPAL) Berbasis Masyarakat, Gunung Kidul, Yogyakarta. Jurnal Sains dan Teknologi Lingkungan, Volume 8, Nomor 1: 46-55.

11. Philip and Ralph, (2011), SWITCH Training kit, Integrated Urban Water Management in the City of the Future. Module 5 Wastewater - Exploring the options, ICLEI European Secretariat GmbH, Freiburg, Germany.

12. Anonim,, (2013), Rencana Aksi Mitigasi Dan Adaptasi Perubahan Iklim Dalam Kerangka Pengelolaan Sumberdaya Air Das Citarum Di Kota Cimahi, Climate Change Mitigation and Adaptation Action Plans, Under Framework Water Resource Management at Citarum River. Pemerintah Daerah Jawa Barat.

13. Anonim, (2011), Database Sarana dan Prasarana Air Bersih Kota Cimahi. Pemerintah Kota Cimahi,

14. Hamandi, D., N. Iskandar,. dan A. Salahudin (2006), Konservasi Air Tanah di Daerah Bandung dan Sekitarnya. Buletin Geologi Tata Lingkungan, vol. 16, no.2 : 41-57.

15. Anonim, (2012). Rencana Tata Ruang Wilayah Kota Cimahi 2012-2032, Pemerintah Kota Cimahi, 
16. Igusman, I. dan Purwadi, D., (2014), Pengaruh Sistem Sanitasi Terhadap Kualitas Air Sumur Dangkal Pada Perumahan Tipe Kecil Di Kota Mojokerto. Rekayasa Teknik Sipil Vol. 3 Nomer 3/rekat/14: 195 - 204.

17. Effendi, H., (2003), Telaahan Kualitas AirBagi Pengelola Sumber Daya dan Lingkungan Perairan. Kanisius, Yogyakarta.

18. Hutasoit, L.M., (2009), Kondisi Permukaan Air Tanah dengan dan tanpa Peresapan Buatan di Daerah Bandung: Hasil Simulasi Numerik. Jurnal Geologi Indonesia, Vol.4 No. 3: 177-188.

19. Anonim, (2013), Laporan Akhir-Identifikasi Potensi Muka Air Tanah di Kota Cimahi. Pemerintah Kota Cimahi

20. Kusumosanyoto dan Sunjoto, (2009), Pembangunan Sumberdaya Air Dalam Dimensi Hamemayu Hayuning Bawono. Pidato Pengukuhan Jabatan Guru Besar. Edisi Saintifik. Fakultas Teknik, UGM.

21. Anonim, (2015), Laporan Advis Teknis IPAL Kota Cimahi. Puslitbang Perumahan dan
Permukiman. Kementerian Pekerjaan Umum dan Perumahan Rakyat

22. Anonim, (2015), Perencanaan Sistem Pengolahan Air Limbah Domestik. Pemerintah Kota Cimahi,

23. Hammer, (2008), Constructed Wetland for Wastewater Treatment: Municipal, Industrial, and Agricultural. Vol. 4 no 4, Chelsea, Lewis Publisher.

24. Anabella, Ferral, Martin, Tagle, Sarmiento, Eugenia, Alaniz, Alberto, Ferral, (2014), Assessment, Monitoring And Protection Of Groundwater Pollution In Urban Areas Cordoba City - Argentina.European Scientific Journal special edition vol.3 ISSN: 1857 - 7881 (Print) e - ISSN 1857- 7431.

25. Packialakshmi, S., Balaji and T. Kumaresan, (2015), Inducing Recharge of Groundwater by Treated Waste Water - A Pilot Study in Southern Chennai Metropolitan Area.Indian Journal of Science and Technology, Vol. 8 (11), DOI: 10.17485/ijst/2015/v8i11/71806, ISSN (Online) : 0974-5645. 